\title{
二円筒試験におけるすずめつき熱拡散処理居の焼付き強さ* (二硫化モリブデンを添加したグリースの場合)
}

\author{
灘 野宏 正*1, 中迫 正一*1, 河野正 来*1 \\ Seizure Resistance of Thermally Diffused Layer after Sn-Plating \\ in Two-Roller Test \\ (Case of Grease with Molybdenum Disulfide Additive)
}

Hiromasa NADANO, Masakazu NAKASAKO and Masaki KOHNO

\begin{abstract}
To clarify the seizure resistance of stainless steel rollers of which the surface layer was thermally diffused after being Sn-plated, a two-roller test was carried out with grease lubrication. From the tests, the following results were obtained. The coefficient of friction of the roller with the Sn-diffused layer at the incipient stage of seizure, when lubricated with grease containing molybdenum disulfide additive, was considerably higher than that without a diffused layer. The load at the incipient stage of seizure of the roller with the diffused layer was larger than that of the roller without the diffused layer, and the effect of the diffused layer on the increase in the seizure resistance of the roller was recognized. However, the seizure resistance of the roller was decreased due to the molybdenum disulfide additive. The critical temperature of the roller with the diffused layer was higher than 400 ${ }^{\circ} \mathrm{C}$, and this was higher than that without a diffused layer.
\end{abstract}

Key Words : Tribology, Surface Treatment, Surface Temperature, Sn-Diffused Layer, Stainless Steel, Grease, Molybdenum Disulfide, Two-Roller Test, Seizure Resistance

\section{1. 緒}

グリース潤滑の場合, 油潤滑と比べると油封構造が 簡素化できるため,グリースで曾面を潤滑する曾車隇 速装置が数多く見受けられ，この方面の研究として福 永らの報告(1) がある. 小形の電気機器の減速装置では, グリースを歯面に塗布する状態で使用される場合が数 多くあり，このような使用状況においても十分な動力 を伝達できる苗車の製作が要求される.

ステンレス鋼製歯車の負荷性能の向上に関する基礎 的研究として行ったグリースを鋼球に塗布した場合の 四球試験によれば，表面に約 $6 \mu \mathrm{m}$ のすずめっき熱拡 散処理層(2) (以下，㹡散層と称す)を施したステンレス 鋼球の焼付き強さは，末処理球の場合と比して $2 \sim 4$ 倍向上することを明らかにした．また，素地の表面に その熱伝導特性とは異なる被膜を施した球同士がすべ り接触する場合の瞬間温度上昇の計算結果によれば, 瞬間温度上昇值は被膜の熱拡散率の影響が顕著であ り，拡散層をステンレス鋼球に施すことにより表面温 度は著しく低下することが明らかになった(3)。この結 果，拡散層は焼付きやかじりの早期発生を抑制できる

* 原稿受付 1996 年 2 月 13 日.

*1 证負, 哭工業高等専門学校(西 737 與市阿賀南 2-2-11).
被膜であり，すずめっき熱㹡散処理法は表面改質のた めの有効な一方策と考えられる。

本研究ては次の段階として, 歯車の接触状態に近い 二円筒試験の場合について，拡散層を施したステンレ ス鋼製の円筒を使用して，グリースを円筒表面に染布 した状態でこころがりーすべり接触における拡散層の 摩擦特性および焼付き強さを明らかにした。さらに， 既報の四球試験 ${ }^{(3)}$ と二円筒試験の場合の焼付き強さ に関する相関についても言及した。また，表層と素地 の熱伝導特性が異なる円筒同士がころがりーすべり接 触する場合の瞬間温度上昇式を導き, 円筒の焼付き強 さに及ほす表層の影響を表面温度の観点から検討し た。なお，本計算式は，コーティングを施した歯車抢よ び軸受などのコーティング被膜の熱的強さを明らかに する際に重要と考えられる。

\section{2. 钎 号}

$a$ : 円筒 $\mathrm{A} / \mathrm{C}$ 形の場合のだ円状压痕の長径(円筒 の軸方向)の $1 / 2$, あるいは熱源の移動方向に 直角方向の接触幅の $1 / 2 \mathrm{~m}$

$b$ : 円筒 $\mathrm{A} / \mathrm{C}$ 形の場合のだ円状圧痕の短径 (円筒 の軸に直角方向) の $1 / 2$, および円筒 $\mathrm{A} / \mathrm{B}$ 形 の場合の円周方向の圧痕幅の $1 / 2$, あるいは 
熱源の移動方向の接触幅の $1 / 2 \mathrm{~m}$

$K_{i j}$ : 熱伝導率 $\mathrm{W} /(\mathrm{m} \cdot \mathrm{K})$

$K_{0}$ : 次数 0 の変形された第二種のベッセル関数

$l$ : 円筬 B 形の場合の軸方向の接触長さ $\mathrm{m}$

$l_{c i}:$ 表層(拡散層)の厚み $\mathrm{m}$

$P:$ 垂直荷重 $\mathrm{N}$

$q_{0}$ : 熱源の熱量の分布密度の最高值 $\mathrm{W} / \mathrm{m}^{2}$

$t$ : 時間 $\mathrm{s}$

$V_{i}:$ 熱源の移動速度 $\mathrm{m} / \mathrm{s}$

$\theta_{b}$ : 低速側円筒(四球試験では, 回転球)の本体温

度 ${ }^{\circ} \mathrm{C}$

$\theta_{f}:$ 円筒 (四球試験では, 球)の瞬間温度 ${ }^{\circ} \mathrm{C}$

$\theta_{m i}:$ 移動熱源による瞬間温度 ${ }^{\circ} \mathrm{C}$

$\theta_{c r}$ : 焼付き発生の臨界温度 $\left(\theta_{f}+\theta_{b}\right) \quad{ }^{\circ} \mathrm{C}$

$x_{i j}$ : 熱拉散率 $\mathrm{m}^{2} / \mathrm{s}$

\section{無次元量}

$$
\begin{aligned}
& L_{i}=V_{i} b /\left(2 x_{i 1}\right) \\
& T_{m i}=\pi K_{i 1} V_{i} \theta_{m i} /\left(2 q_{0} \chi_{i 1}\right) \\
& X=L_{i} x / b=L_{i} \xi \\
& \alpha_{i}=\left(1-\omega_{i}\right) /\left(1+\omega_{i}\right) \\
& \delta_{i}=l_{c i} / b \\
& \omega_{i}=K_{i 2}\left(x_{i 1}\right)^{1 / 2} /\left(K_{i 1}\left(x_{i 2}\right)^{1 / 2}\right)
\end{aligned}
$$

ただし，添字 $i=1,2$ はそれぞれ低速側円筒および 高速側円筒を表し、添字 $j=1,2$ はそれぞれ表層およ び素地を表す。

\section{3. 瞬间温度の計算式}

図 1 に示すように, 表層と素地の熱云導特性が異な る低速側円筒が周速度 $V_{1}$ で回転し，低速側円筒とは 異なった熱伝拿特性の高速側円筒が周速度 $V_{2}$ で回転 する二円筒試験の場合の瞬間温度上昇について考え

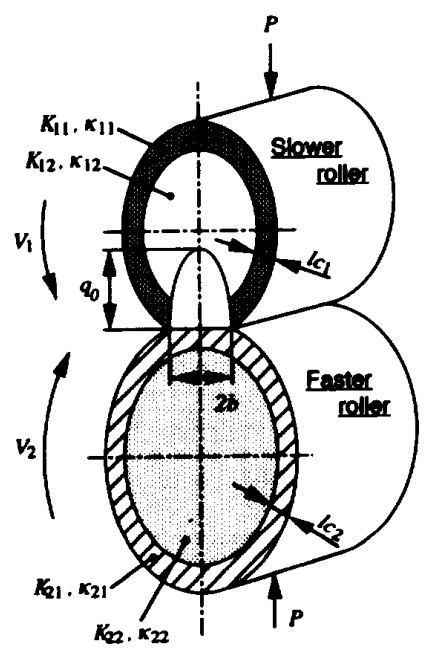

Fig. 1 Roller model for calculation of surface temperature
る.ここでは，表面に発生した瞬間熱源が二次元熱流 (熱源の移動方向である $x$ 軸および円筒の深さ方向で ある $z$ 軸への熱流) とした場合の瞬間温度上昇式を次 の仮定により求めた。

（1）円筒の大きさはその接触面と比へて大きいの で, 円筒を半無限体とする.

（2）熱伝埒率や熱拡散率などは温度に関して一定 とする.

（3）接触面に発生した熱量はすべて両円筒に流入 する。

（4）表層と素地の境界面における熱損失はない. また, 接触面上に発生する熱量の分布密度の形状は接 触応力と円筒の圧縮降伏強さによって，下記のように 決定できるものと仮定する。

\section{$3 \cdot 1$ 接触面が弾性変形する场合の温度上年式}

円筒に作用する接触応力がその圧縮降伏強さより小 さい場合には，接触面は弾性変形するものと考えられる ので，接触面上には放物線状に熱量の密度が分布する ものと仮定できる.ここで, 円筒の接触面内における 表面温度が等しくなるように低速側円筒と高速側円筒 に流入する熱量の割合を求めると, 円筒の瞬間温度上 昇 $\theta_{f}$ は, 無次元量を使って表すと次式で表される.

$$
\theta_{f}=\frac{2 q_{0} x_{11} L_{1} T_{m 1} T_{m 2}}{\pi V_{1}\left(K_{21} L_{2} T_{m 1}+K_{11} L_{1} T_{m 2}\right)}
$$

それぞれの円筒の瞬間温度の無次元量 $T_{m i}$ は次式て 与えられる(付録)。

$$
\begin{aligned}
& T_{m i}=\left[\int_{L_{i}(\varepsilon-1)}^{L_{i}(\varepsilon+1)}\left(1-\xi^{2}+\frac{2 u \xi}{L_{i}}-\frac{u^{2}}{L_{i}^{2}}\right) K_{0}(u) e^{-u} d u\right. \\
& \quad+2 \sum_{n=1}^{\infty} \alpha_{i}^{n} \int_{L_{1}(\xi-1)}^{L_{(}(\xi+1)}\left(1-\xi^{2}+\frac{2 u \xi}{L_{i}}-\frac{u^{2}}{L_{i}^{2}}\right) \\
& \left.\quad \times K_{0}\left\{\sqrt{u^{2}+\left(2 n L_{i} \delta_{i}\right)^{2}}\right\} e^{-u} d u\right] \cdots \cdots \cdots \cdots(2)
\end{aligned}
$$

この有限積分の計算にはガウス・ルジャンドルの積 分公式(4)を使用した。

なお，熱量の分布密度の最高值 $q_{0}$ は，後述する試験 円筒の形状 (図 3 を参照)の組含せ (低速側/高速側)に より異なる。

線接触の A/B 形の場合では, 接触面は長方形とな り，その面上に半放物線柱状に熱量の密度が分布する ものと仮定する.この分布密度の総和は摩擦により発 生した熱量に等しいので，q0は次式で与えられる。

$$
q_{0}=\frac{3 \mu P\left|V_{1}-V_{2}\right|}{4 b l}
$$

同様にして，点接触の $\mathrm{A} / \mathrm{C}$ 形の場合では，接触面は だ円形となり，その面上にだ円放物体状に熱量の密度 が分布するものと考えられ，q0 は

$$
q_{0}=\frac{2 \mu P\left|V_{1}-V_{2}\right|}{\pi a b}
$$


で与えられる。

\section{$3 \cdot 2$ 接触面が塑性变形する場合の温度上界式}

円筒に作用する接触応力がその厌縮降伏強さより大 きい場合には，接触面は塑性変形するため，その面上に 矩形状の熱量の密度が分布するものと仮定できる。こ の場合の川筒の瞬間温度上昇 $\theta_{f}$ は，無次元量を使っ て表すと式（1）と同様となり，それぞれの山筒の瞬間 温度の無次元量 $T_{m i}$ は次式(3)で与えられる。

$$
\begin{aligned}
& T_{m i}=\left[\int_{L_{i}(\xi-1)}^{L_{i}(\xi+1)} K_{0}(u) e^{-u} d u\right. \\
& \left.\quad+2 \sum_{n=1}^{\infty} \alpha_{i}^{n} \int_{L_{i}(\xi-1)}^{L_{i}(\xi+1)} K_{0}\left\{\sqrt{u^{2}+\left(2 n L_{i} \delta_{i}\right)^{2}}\right\} e^{-u} d u\right]
\end{aligned}
$$

熱量の分布密度の最高值 $q_{0}$ に関しては, $\mathrm{A} / \mathrm{B}$ 形の 場合では，長方形の接触面上に角柱状に熱量の密度が 分布するものと考えられ， $q_{0}$ は次式で与えられる。

$$
q_{0}=\mu P \mid \frac{V_{1}-V_{2} \mid}{2 b l}
$$

A/C 形の場合では，だ归形の接触面、ににだ円柱状に 熱量の密度が分布するものと考えられ、,

$$
q_{0}=\frac{\mu P\left|V_{1}-V_{2}\right|}{\pi a b}
$$

で与えられる。

一例として，本実験に近い計算条件である，熱源の 移動速度の無次元量が $L=1$ の場合における角柱状分 布熱源による瞬間温度の無次元量 $T_{m}$, 表層の厚みの 無次元量 $\delta$ およひ表層と素地の熱伝導特性の比 $\omega$ の 関係を図 2 に示す。 $0.1<\delta<2 て ゙ は ， T$ に及ぼす表層 の)厚みの影響は顕著に現れる。しかしながら， $\delta<0.1$ では $T_{m}$ に及ほす表層の厚みの影響は極めて小さい。 したがって，表泊上に熱伍導特性の良好な被膜が存在 する限り，摩摖によって発生する瞬間温度.上昇は低く 現れることがおかる。

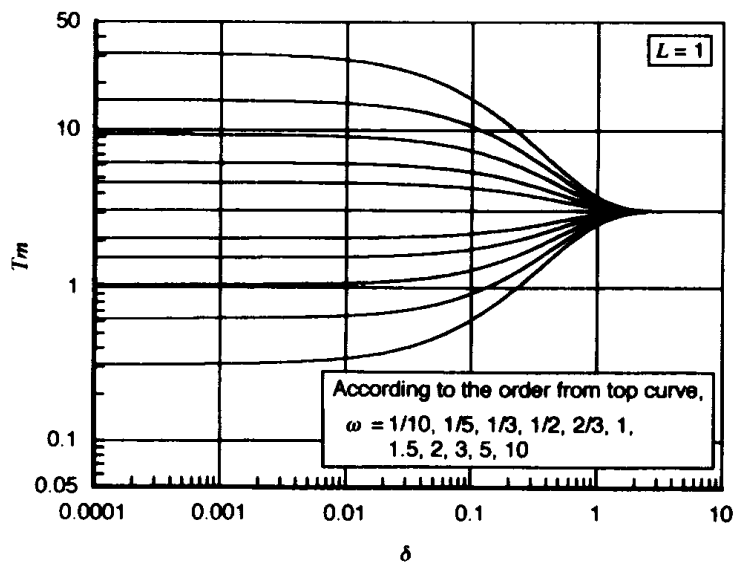

Fig. 2 Relationship between $T_{m}$ and $\delta$

\section{4. 試 跧 方 法}

4・1 試験円简 二円筒試験に使用した試験円筒 の形状と寸法を図 3 に示す. 円筒形状の組合せ (低速 側/高速側)としては，線接触の A/B 形および点接触 の $\mathrm{A} / \mathrm{C}$ 形とした。なお，試験中の円筒の本体温度を測 定するため, 円筒 Aについては, 外周面から $2.5 \mathrm{~mm}$ 内側の位置で,円筒の側面に垂直に直径 $1 \mathrm{~mm}$, 深さ $5 \mathrm{~mm}$ の穴をあけた。

表 1 に試験円筒の記号を示す。なお，既報の四球試 験結果と比較するため四球試験の場合を付記した。円 筒の材質は，マルテンサイト系ステンレス鋼 SUS 440 $\mathrm{C}$ とし，四球試験の場合と同様，1060兄で油焼入れ後， $150^{\circ} \mathrm{C}$ で焼戻しを行った. 円筒表面のマイクロビッカー 又硬さ $H V$ (測定荷重 $196 \mathrm{~N}$ ) は約 680 である。

円筒の拨散処理の工程としては, 溶㓮・アルカリ脱 脂, 洗浄および酸化膜除去の前処理を行った後すず

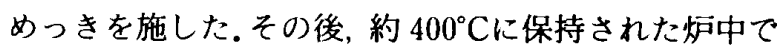
熱拡散処理を行い, 円筒表面に金属間化合物 $\mathrm{FeSn}_{2}$ の 拡散層を形成させた。円筒表面のマイクロビッカース 硬さ $H V$ は約 700 であり, 拡散処理前と比して硬さ はわずかに高い。

表 2 に拡散処理を施した場合の㹡散層の厚みを示 す.

Table 1 Combinations of test specimens

\begin{tabular}{c|c|c|c|c}
\hline \multirow{2}{*}{ Symbol } & \multicolumn{2}{|c|}{ Two-roller test } & \multicolumn{2}{c}{ Four-ball test } \\
\cline { 2 - 5 } & \multicolumn{2}{|c|}{ Sn-diffused layer } & \multicolumn{2}{c}{ Sn-diffused layer } \\
\cline { 2 - 5 } & Slower roller & Faster roller & Rotation ball & Stationary ball \\
\hline UA /UB & Without & Without & - & - \\
\hline UA /UC & Without & Without & - & - \\
\hline SA /SB & With & With & - & - \\
\hline SA /SC & Whit & With & - & - \\
\hline UC* /UC* & - & - & Without & Whithout \\
\hline SC* /SC* & - & - & With & With \\
\hline
\end{tabular}

Symbol $\mathrm{C}^{*}$ stands for the balls of $19.05 \mathrm{~mm}$ in diameter.

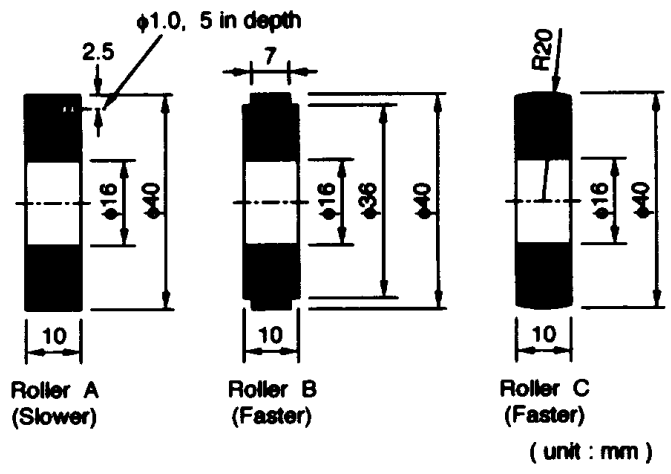

Fig. 3 Type of roller 
円筒の場合の拡散層の厚みは球の場合と比して $1 \sim 3$ $\mu \mathrm{m}$ 大きい. また, 拡散処理後の各試験円筒の軸方向の 表面粗さ $R_{\max }$ は 2.5 2.8 $\mu \mathrm{m}$ であり, 試験円筒の形 状による表面粗さの違いは認められなかった。しかし ながら, 処理後の $R_{\max }$ は処理前のそれと比して 2 倍 程度大きい。

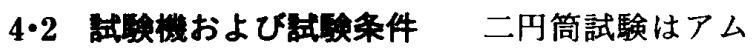
スラー摩擦試験機を用いて行った. 垂直荷重は油圧に より与え, 摩擦力は回転軸に連結した振り子の摩摖卜 ルクによる変位を差動トランスで検出して測定した。

円筒の本体温度の測定に関しては, 図 3 に示した低 速側円筒(A 形)の穴に摷入した CA 熱電対をスリッ プリングに接続し，その熱起電力を記録計で読取っ た.

表 3 に試験条件を示す. 試験は荷重渐増式で行い, 各試験段階では最初の $10 \mathrm{~s}$ を荷重上昇区間, 残りの 5 $\mathrm{s}$ を荷重一定区間として, 焼付きが発生するまで連続 的に行った。なお, 四球試験の場合の摩擦距離にほほ 等しくなるように, 二円筒試験の場合の試験段階にお

Table 2 Thickness of Sn-diffused layer of test specimens

\begin{tabular}{l|l|l}
\hline \multirow{2}{*}{ Symbol } & $\begin{array}{l}\text { Thickness of } \\
\text { Sn-diflused layer } \mu \mathrm{m}\end{array}$ \\
\hline \multirow{3}{*}{ Roller } & $\mathrm{SA}$ & 7.1 \\
\cline { 2 - 3 } & $\mathrm{SB}$ & 7.7 \\
\cline { 2 - 3 } & $\mathrm{SC}$ & $\mathbf{8 . 5}$ \\
\hline Ball & $\mathrm{SC}^{*}$ & 5.6 \\
\hline
\end{tabular}

Table 3 Experimental conditions in two-roller and four-ball tests

\begin{tabular}{|c|c|c|c|c|c|}
\hline & \multicolumn{2}{|c|}{ Two-roller test } & \multirow[b]{2}{*}{$\begin{array}{c}\text { Four-ball } \\
\text { test }\end{array}$} \\
\hline & & & $\begin{array}{c}\text { Slower } \\
\text { roller } \\
\text { A }\end{array}$ & $\begin{array}{c}\text { Faster } \\
\text { roller } \\
\text { B, C } \\
\end{array}$ & \\
\hline \multicolumn{2}{|c|}{ Revolution speed } & $N$ pm & 124 & 382 & 400 \\
\hline \multicolumn{2}{|c|}{ Peripheral velocity } & $v \mathrm{~m} / \mathrm{s}$ & 0.26 & 0.80 & - \\
\hline \multicolumn{2}{|c|}{ Specific sliding } & $\%$ & -208 & 67.5 & - \\
\hline \multicolumn{2}{|c|}{ Sllding velocity } & $V_{s} \quad \mathrm{~m} / \mathrm{s}$ & \multicolumn{2}{|c|}{0.54} & 0.23 \\
\hline \multicolumn{2}{|c|}{ Normal load } & $\boldsymbol{P}$ & \multicolumn{2}{|c|}{$\begin{array}{c}970 \sim 7300 \\
(27 \text { test ranges })\end{array}$} & $\begin{array}{c}86.3 \sim 1616 \\
(39 \text { test } \\
\text { ranges })\end{array}$ \\
\hline \multirow{2}{*}{$\begin{array}{l}\text { Maximum } \\
\text { Hertzian } \\
\text { contact } \\
\text { stress GPa }\end{array}$} & \multicolumn{2}{|c|}{ Roller pair A/B } & \multicolumn{2}{|c|}{$0.71 \sim 1.94$} & \multirow{2}{*}{$2.11 \sim 5.61$} \\
\hline & \multicolumn{2}{|c|}{ Roller pair A / C } & \multicolumn{2}{|c|}{$2.32 \sim 4.54$} & \\
\hline \multicolumn{2}{|c|}{ Incremental toad } & $P_{i}$ & \multicolumn{2}{|c|}{243} & 41 \\
\hline \multicolumn{2}{|c|}{$\begin{array}{l}\text { Running time in } \\
\text { respective ranges }\end{array}$} & 8 & \multicolumn{2}{|c|}{15} & 30 \\
\hline
\end{tabular}

Table 4 Properties of grease

\begin{tabular}{l|c|c|c|c|c}
\hline Thickener & $W \%$ & \multicolumn{4}{|c}{ Base oil } \\
\hline \multirow{3}{*}{ PTFE } & \multirow{3}{*}{40} & \multicolumn{2}{|c|}{$\begin{array}{r}\text { Kinematic viscosity } \\
\mathrm{mm}^{2} / \mathrm{s}\end{array}$} & \multicolumn{2}{|c}{$\begin{array}{c}\text { Density } \\
\mathrm{kg} / \mathrm{m}^{3}\end{array}$} \\
\cline { 3 - 6 } & & $20 \mathrm{C}$ & $60 \mathrm{C}$ & $20^{\circ} \mathrm{C}$ & $60^{\circ} \mathrm{C}$ \\
\cline { 3 - 6 } & & 500 & 95 & 1894 & 1817 \\
\hline
\end{tabular}

ける運転時間を設定した。

グリース潤滑剤としては，ふっ素系のパーフロ・ポ リエーテルを使用し，二硫化モリブデンを添加する前 の基油の諸特性および増ちょう阂の含有率を表 4 に示 す。供試グリースとしては, 平均粒径が約 $15 \mu \mathrm{m}$ の二 硫化モリブデンを, 添加浱度 (重量\%)が 30\%になるよ うに調合したグリースおよび無添加のグリースの 2 種 類を使用した。

両円筒の外周面に薄く塗布した後, 接触部入口に少 量のグリースを補充して試験を開始し、試験中にはグ リースの補給は行わない, なお, 零囲気の温度は室温 $\left(20 \pm 3^{\circ} \mathrm{C}\right)$ とした。

\section{5. 実験結果および考察}

$5 \cdot 1$ 摩㨲係数 二円筒試験における垂直荷重 $P$ に対する摩擦係数 $\mu$ の変化を図 4 に示す. 図 4 中の記 号 S, Uは拡散層の有無を, 記号 A, B，C は円筒の形 状を表す. 例えば，記号 UA/UB は拡散末処理の A 形 (低速側) と拡散末処理の B 形 (高速側)の試験円筒の

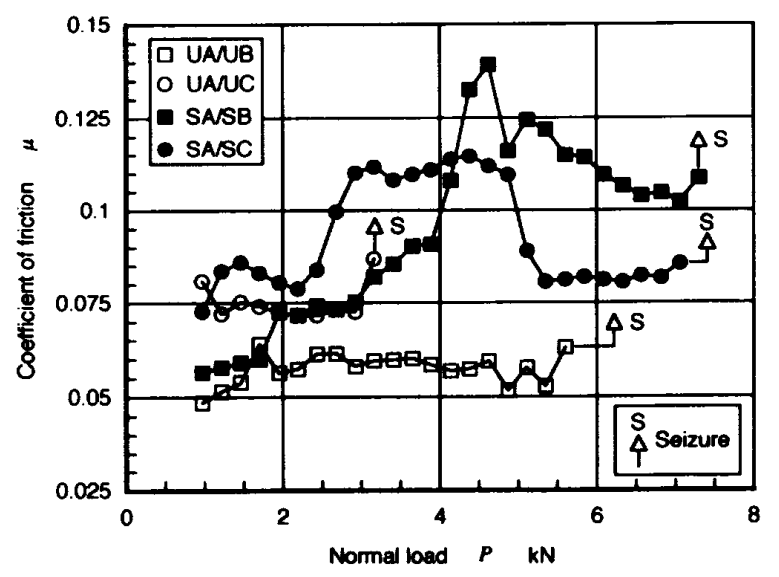

(a) $\mathrm{MoS}_{2} 0 \%$

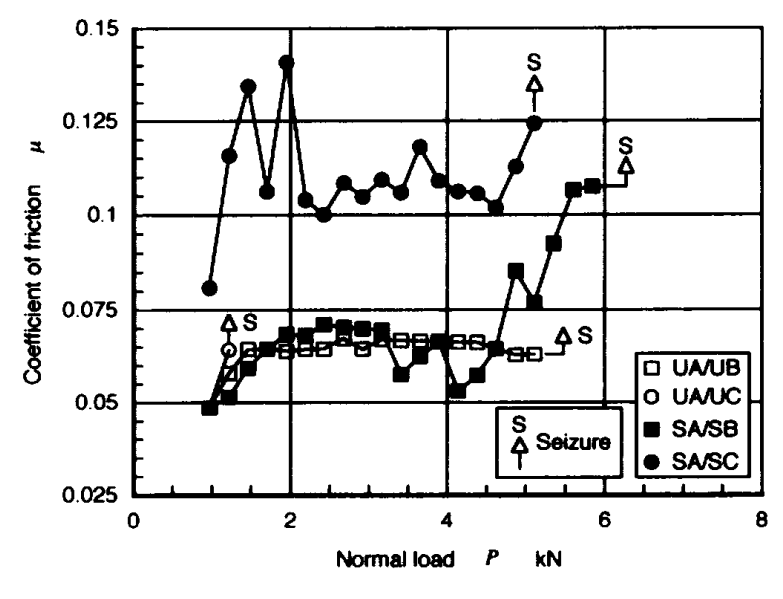

(b) $\mathrm{MoS}_{2} 30 \%$

Fig. 4 Relationship between coefficient of friction and normal load in two-roller test 
組合せを示す。また，摩擦係数の測定は各試験円筒に ついて 3 回行っており, 摩擦係数のばらつきは, 最も 大きいもので 0.03 程度である.しかしながら, 垂直 荷重 $P$ に対する摩擦係数 $\mu$ の変化は， 3 回の試験を 通してほほ同様の傾向を示し，焼付き直前の荷重にお ける摩擦係数のばらつきは小さく なった. 図 4 は 3 回の湘定のうちの代表的な例を示す.

なお，外周面に塗布したグリースおよび接触部入口 に補充したグリースのほとんどは，試験開始から $3 〜 4$ の荷重段階の間に，円筒の接触域外へ押し出され，遠 心力によって飛ばされるのが観察されており，接触面 は極めて薄いグリース膜で潤滑されているものと考え る.

図 4 (a) は二硫化モリブデンの添加濃度が $0 \%$ の゙ リースの場合を示す。拡散末処理円筒の場合ではいず れの円筒形状の場合も，焼付きが発生する前の荷重段 階まで摩擦係数はほほ一定値を示す。しかしながら， 点接触の $\mathrm{A} / \mathrm{C}$ 形の場合の摩擦係数は線接触の $\mathrm{A} / \mathrm{B}$ 形の場合と比して 0.01 程度大きく, しかも $\mathrm{A} / \mathrm{C}$ 形の 場合の焼付き発生時の垂直荷重は $\mathrm{A} / \mathrm{B}$ 形の場合の約 1/2である.これは，点接触の場合のグリース膜厚さは
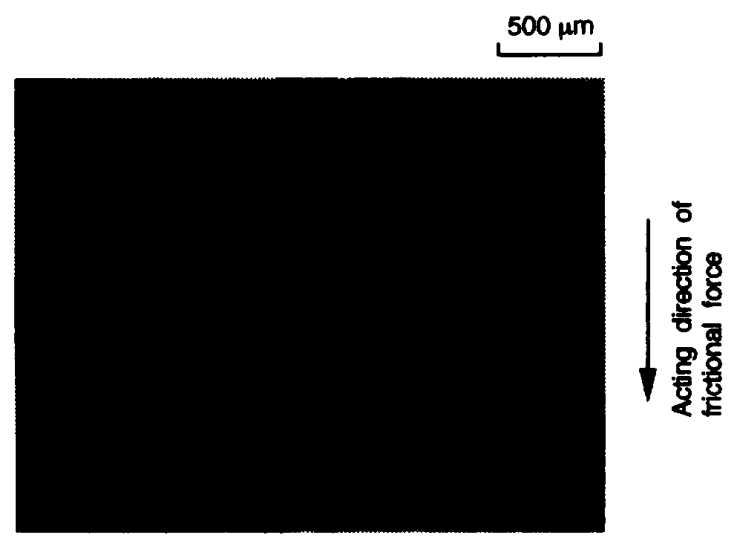

(a) SEM image

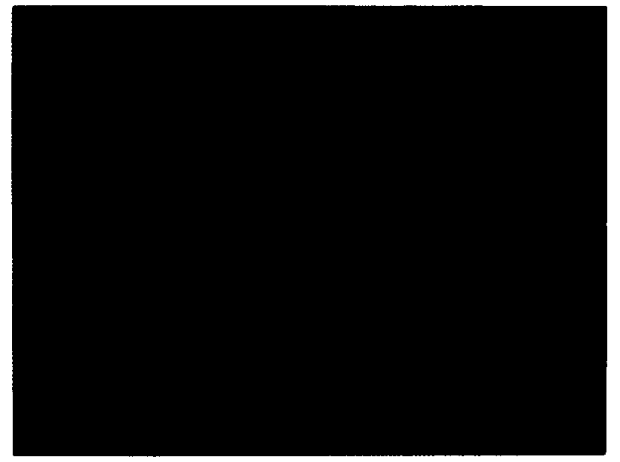

(b) Sn-L $\alpha$ image

Fig. 5 Microphotograph of the contacting surface of roller SB at the incipient stage of seizure for the case of roller pair SA/SB with grease $\mathrm{MoS}_{2}$ additive
線接触の場合と比して薄く，A/C 形の場合の閏滑状態 は $\mathrm{A} / \mathrm{B}$ 形の場合と比して慗いため，早期に焼付きが 発生したものと考えられる。

一方, 拡散処理円筒の場合では, 垂直荷重が約 3 $\mathrm{kN}$ から約 $5 \mathrm{kN}$ までの範井においては, 2〜 $3 \mathrm{~s}$ の周 期が長い付着すべり現象が発生し，摩擦係数は大きく 変動する.また,この荷重籍囲における摩擦係数は 0.1 以上となり, 抎散末処理円筒の場合と比して大きい. これは，㹡散処理による最表面の多孔質層が摩耗し， 接触面に露出した硬い平滑な拡散層同士の凝着, 破断 の繰返しによるものと考えられ, 幅約 $1 \mathrm{~mm}$, 長さ $2 \sim 3 \mathrm{~mm}$, 厚み数 $\mu \mathrm{m}$ の箔状の茶褐色の摩耗片が多数 飛散するのが観察された. 垂直荷重が約 $5 \mathrm{kN}$ を超え ると摩擦係数の変動は減少する。いずれの円筒形状の 場合も $7 \mathrm{kN}$ 付近で焼付きが発生し，拡散処理により 焼付き荷重は著しく増加する。

図 4 (b) は二硫化モリブデンの添加哄度が $30 \%$ の グリースの場合を示す. 拡散末処理円筒の場合では, A/B 形の場合の摩擦係数は, 焼付きが現れる前の荷 重段階までほほ定値を示しており，図4（a)の場合 と比してわずかに大きい，また，A/C 形の場合では， 摩擦係数は $\mathrm{A} / \mathrm{B}$ 形の場合と変わらないが, 試験を始 めた次の荷重段階で焼付きを発生する.いずれの円筒 形状の場合とも，無添加グリースの場合と比して，二 硫化モリブデンの添加により焼付き荷重は低下する。 これは, 二硫化モリブデンの密度は $4800 \mathrm{~kg} / \mathrm{m}^{3}$ (5)で あり，二硫化モリブデンの添加濃度が $30 \%$ のグリース の場合の重量は無添加グリースの場合と比して大き い.したがって，円筒の回転による遠心力により，添加 グリースの場合が無添加グリースの場合と比して飛ば されやすく，接触面上に形成されるグリース膜厚が薄 くなることに起因するものと考えられる.

一方，拡散処理円筒の場合では，A/C 形の場合の摩 擦係数は 0.1 以上であり，A/B 形の場合と比してか なり高く現れる.また, 摩擦係数の変動もかなり大き く, 図 4（a）の場合と同様, 周期が長い付着すべり現 象が現れ，䈃状の摩耗片が飛散するのが観察された。 また,いずれの円筒形状の場合も，無添加グリースの 場合と比して，焼付き荷重は低い。

$5 \cdot 2$ 接触面の状悲 一例として，二硫化モリフ デンの添加濃度が $30 \%$ グリースの場合における円 筒 SA/SB の場合について, 焼付き発生後の高速側円 筒表面の EPMA 写真を図 5 に示す. 焼付きによる損 傷幅は約 $1.4 \mathrm{~mm}$ で, 円筒面のほほ中央部に発生して おり,この部分には Snはほとんど認められない。しか しながら，焼付き部を除いた円筒面にはSnがかなり 
認められる.したがって, 摩耗の進行により薄くなっ た拡散層は焼付き発生直前まで円筒面上に存在するも のと考えられる.

次に, 円筒の接触状態について検討する. 図 6 は接 触幅と垂直荷重 $P$ の関係を示す. 図 6 中, 測定値は, 拡散末処理の両円筒を静止した状態で垂直荷重を加え た場合の接触幅の $1 / 2$ を示す. 接触幅の測定に関して は，低速側円筒表面にすすを薄く付着させて，所定の 垂直荷重を加えた後, 高速側円筒に移着したすすの幅 を読取り䫏微鏡で測定した。したがって，接触面の弾 性回復により，垂直荷重を加えた状態での接触幅と比 して実測值はわずかに縮小するものと考えられる.太 い実線はへルツ接触幅の $1 / 2$ を示す.

線接触の円筒 $\mathrm{A} / \mathrm{B}$ 形の場合では, 接触幅の測定值 はヘルツ接触幅と比して大きい, 最も高い荷重段階 $(P$ $=7.3 \mathrm{kN})$ における単位面積当たりの接触圧力 $P_{m}$ は 約 $1.3 \mathrm{GPa}$ であり，試験円筒の王縮降伏強さ ${ }^{(6)}$ と比 してかなり低く, 接触面は弾性変形の状態と考えられ る.

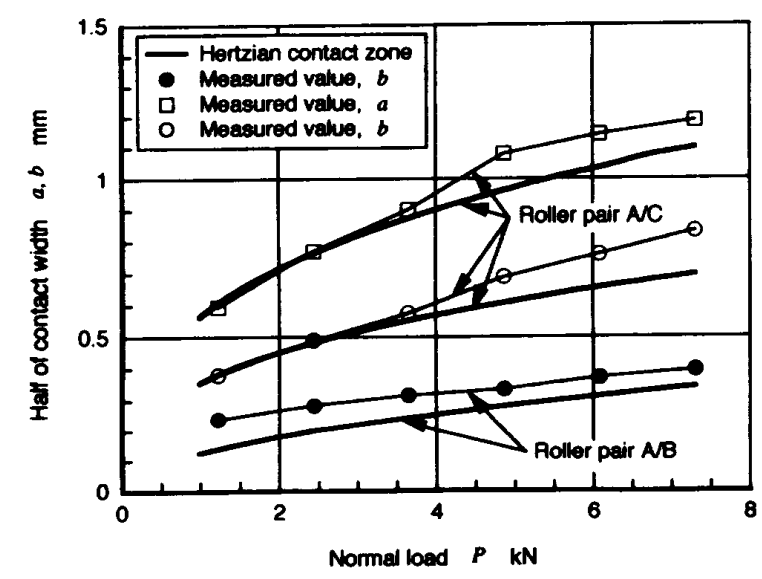

Fig. 6 Variation in contact width against normal load in two-roller test

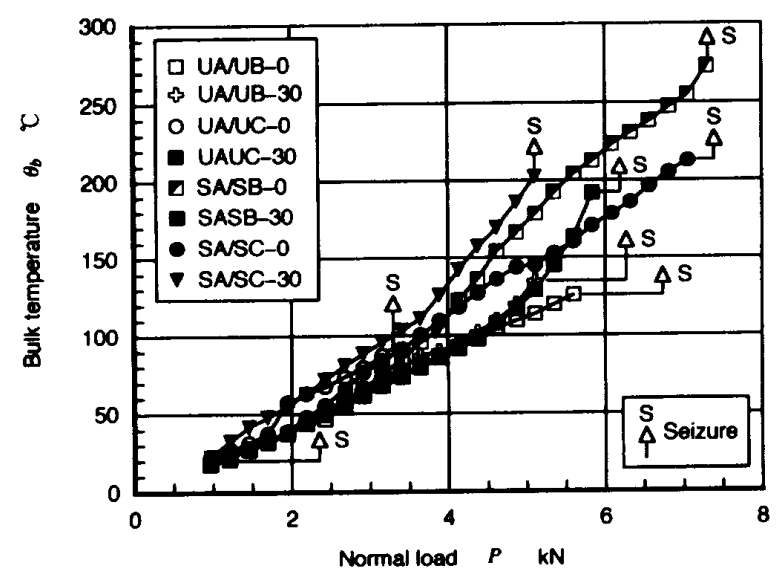

Fig. 7 Variation in bulk temperature against normal load in two-roller test
一方, 点接触の円筒 A/C 形の場合では, $P<$ 約 2.4 $\mathrm{kN}$ では，円筒の軸方向に治った接触幅 $a$ および軸に 直角方向の接触幅 $b$ のいずれの場合も，ほほへルツ接 触幅に等しいか小さい. $P \fallingdotseq 3.5 \mathrm{kN}\left(P_{m} \fallingdotseq 2.2 \mathrm{GPa}\right)$ を 超えると実測值の増加傾向が顕著に現れており, 接触 面は弾性変形の状態から塑性変形の状態へ移行したも のと考えられる.

後述する瞬間温度上昇の計算には, 図 6 に示した接 触幅の測定值を熱源の大きさとして使用した。 なお， 実際の二円筒試験においては, 摩耗の進行や摩擦力の 作用により，図 6 に示す接触幅と比してやや異なるも のと考えられる。

$5 \cdot 3$ 円简の本体温度 図 4 に示した試験円筒の 組合せに対する低速側円筒の本体温度 $\theta_{b}$ の測定值を 図 7 に示す. 図 7 中, 記号 UA/UB は試験円筒の組合 せを表し, 記号の次の数字 0,30 は二硫化モリブデン の添加濃度が $0 \%, 30 \%$ の゙リースの場合を表す.払散 処理円筒の場合では焼付き発生時の本体温度は, $200^{\circ} \mathrm{C}$ 近くかそれ以上に達しており，拡散末処理円筒 の場合のそれと比して著しく高い。また，摩擦係数の 変動と比して本体温度のそれは極めて小さく, 垂直荷 重の增加に伴って本体温度は徐々に上昇する。

$5 \cdot 4 p V$ 优 焼付き発生の限界值の一つである $p V$ 值を図 8 に示す. $p$ はへルツ応力 $[\mathrm{GPa}]$ を表し, 3 回の実験に対する平均值を表すＶVはすべり速度 $[\mathrm{m} /$ s] を表す。図 8 中, 矢印は最終荷重段階においても焼 付きが発生しなかったことを表す。

焼付き強さに及ほすす硫化モリブデンの添加の有無 の影警について検討する.二円筒試験の場合では，二 硫化モリブデンを添加したグリースの場合の $p V$ 值は 無添加グリースの場合と比して同程度か小さい.これ は, 前述のように, 添加グリースの場合の膜厚が無添 加グリースの場合のそれと比して薄くなることに起因

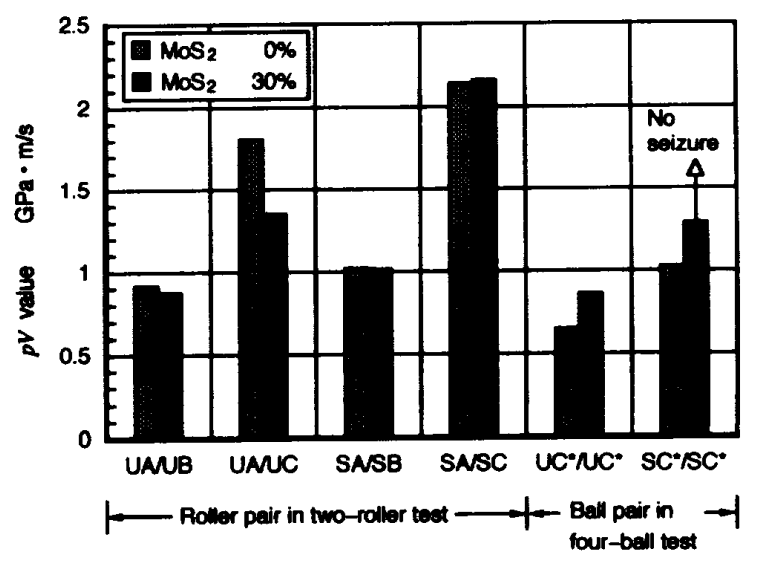

Fig. $8 p V$ value at seizure 
するものと考えられる。しかしなから，四球試験の場 合では，添加グリースの場合の $p V$ 值は無添加グリスの場合の約 1.3 倍である。これは，4個の試験球に 囲まれた空間に補充されたグリースは，遠心力の作用 により飛ばされ難いため，二硫化モリブデンの添加に より接触面の焼付きの発生が抑制されたものと考えら れる.

一方, 焼付き強さに及ほす拡散層の有無の影響に関 しては，四球試験および二円筒試験における同じ接触 形態の試験円筒に対する $p V$ 值は，拡散処理を施した 場合が拡散末処理の場合と比して大きく現れる。した がって，拡散処理に伴う焼付き強さの増加傾向に関し ては，四球試験機による試験結果と二円筒試験機によ るそれとの相関はかなり認められる。

次に, 焼付き強さに及ほす接触形態の影響に関して は, 点接触の $\mathrm{A} / \mathrm{C}$ 形の場合の $p V$ 値は線接触の $\mathrm{A} / \mathrm{B}$ 形の場合のそれと比してかなり大きい.しかしながら， 接触形態が同じ点接触である $\mathrm{C}^{*} / \mathrm{C}^{*}$ 形と $\mathrm{A} / \mathrm{C}$ 形を比 較すると, 前者の $p V$ 值は後者のそれの $1 / 3 \sim 1 / 2$ と なる。

$5 \cdot 5$ 烤付き臨界温度 二円筒試験および四球試 験における焼付き臨界温度 $\theta_{c r}$ を図 9 に示す。焼付き 臨界温度としては，焼付き発生直前における低速側円 筒の本体温度の測定值 $\theta_{b}$ と瞬間温度上昇の計算值 $\theta_{f}$ との和を表す。また，四球試験の場合については，既報 の臨界温度を使用した。

Table 5 Thermal properties of SUS $440 \mathrm{C}$ and Sn

\begin{tabular}{c|c|c}
\hline & SUS440C $(7)$ & Sn (8) \\
\hline $\begin{array}{c}\text { Thermal conductivity } \\
K, W /(m \cdot K)\end{array}$ & 29.27 & 64.0 \\
\hline $\begin{array}{c}\text { Thermal diffusivity } \\
\kappa . \mathrm{m}^{2} / \mathrm{s}\end{array}$ & $7.38 \times 10^{-6}$ & $3.89 \times 10^{-5}$ \\
\hline
\end{tabular}

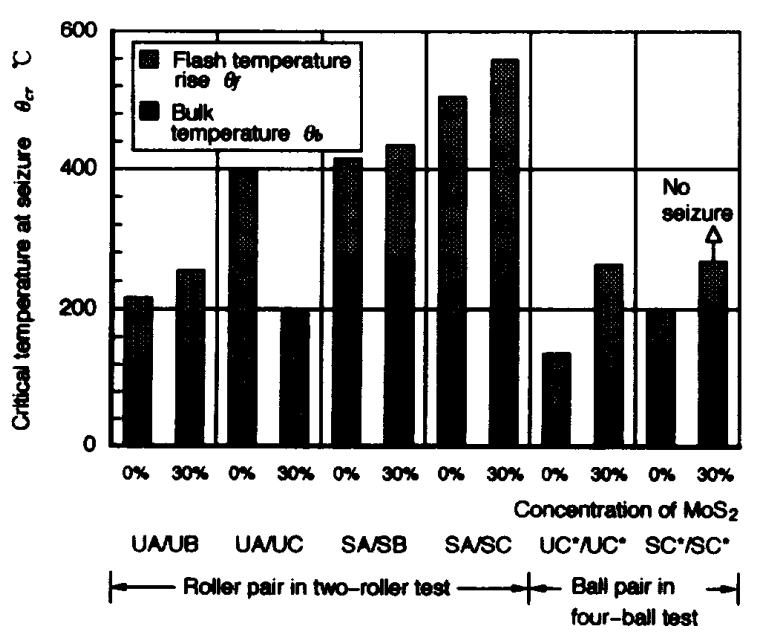

Fig. 9 Critical surface temperature at seizure
瞬間温度上昇值の計算に関しては，試験円筒 SA/ $\mathrm{SC}$ の場合には，前述のように，焼付き直前において 接触面全体が塑性変形しているものと考えられるた め, 熱源の熱量密度の分布を等分布形状とし, $3 \cdot 2$ 節 の計算式を用いた。それ以外の場合には，焼付き直前 における接触面は弾性変形の状態と考えられるため, 熱源の熱量密度は円周方向に沿って放物線状に分布す るものと仮定し，3・1 節の計算式を用いた。また，摩擦 係数としては，焼付き直前の測定值を用いた。なお，試 験円筒の熱的定数值としては，表 5 の值を使用し，拡 散層はすずにより構成されているものと仮定した。

二円筒試験の場合では，㹡散処理を施した試験円筒 の臨界温度はいすれの形状の場合も $400^{\circ} \mathrm{C}$ 以上あり， 㹡散末処理円筒の場合 (UA/UC-0 の場合を除く)と比 して著しく高い。したがって，拡散処理を施した SUS $440 \mathrm{C}$ 鋼製柬車は, 高負荷の条件下で, グリース を歯面に薄く塗布した運転状況においても十分な動力 を伝達できるものと考えられる。

また, 円筒の形状の違いにより大きく変動する $p V$ 值と比して, 臨界温度 (UA/UC-0の場合を除く)では その形状による変動が比較的小さい。したがって，臨 界温度は接触形態, 表面被膜処理などの違いを包括し た総合的な焼付きに対する指標值と考えられる。しか しながら，四球試験結果に対する焼付き臨界温度は， 二円筒試験結果に対するそれと比してかなり低く現れ ており，四球試験における焼付き臨界温度を二円筒試 験の場合に直接適用できない.

\section{6. 結}

すずめつき熱拡散処理を施したステンレス鋼 SUS $440 \mathrm{C}$ の円筒について, 二円筒試験を行った結 果, 次のことが明らかになった。

(1) 二硫化モリブデンの添加濃度が $0 \%$ のグリー スの場合では，拡散未処理円筒の摩擦係数は焼付きが 発生する前の荷重段階まで 0.075 以下で, ほほ一定值 を示す．拡散処理円筒の場合では，荷重の上昇に伴っ て摩擦係数は大きく変動し，拡散末処理円筒の場合と 比してかなり大きい.

（2）二硫化モリブデンの添加濃度が $30 \%$ のグリ ースの場合では, 線接触の拡散末処理円筒の摩擦係数

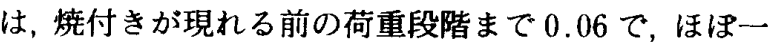
定值を示す，拡散処理円筒の摩擦係数は，接触形態に より異なるが，焼付き前の荷重段階では，0.1 以上と なる。

（3）㹡散処理円筒の焼付き荷重は，抁散末処理円 筒のそれと比してかなり大きく現れ，焼付き強さに及 
ほす拡散層の効果が認められる。しかしながら，二硫 化モリブデンの添加により，円筒の焼付き荷重はやや 低下する。

（4）二円筒試験の場合では，㹡散処理を施した試 験円筒の焼付き臨界温度はいずれの形状の場合も $400^{\circ} \mathrm{C}$ 以上あり，拡散末処理円筒の場合と比して著し く高い。また，接触形態により大きく恋動する $p V$ 值 と比して, 臨界温度の変動は比較的小さい.しかしな がら, 四球試験の場合の臨界温度は, 二円筒試験の場 合のそれと比してかなり低く現れており，四球試験に おける臨界温度を二円筒試験の場合に直接適用できな い.

最後に，本研究を遂行する上ですずめっき熱拡散 処理を実施していただいた同和ケミカル(株)に謝意を 表する。

\section{付録 接触面が弾性変形する埸合の 温度上年式}

図 10 に示すように, 熱量の分布密度 $q\left(x^{\prime}\right)$

$$
q\left(x^{\prime}\right)=q_{0}\left(1-\frac{x^{\prime 2}}{b^{2}}\right) \quad\left(-b \leqq x^{\prime} \leqq b\right)
$$

で表される放物線状分布熱源が， $x$ 軸に沿って速度 $V$ で移動するとき，時間 $\left(t-t^{\prime}\right)$ 後の表面上の点 $(x, 0)$ の 表面温度は, 次式で与えられる。

$$
\begin{aligned}
& \theta=\frac{q_{0}}{2 \pi K_{1}}\left[\int_{0}^{\infty} \int_{-b}^{b} \frac{\left(1-\frac{x^{2}}{b^{2}}\right)}{\left(t-t^{\prime}\right)}\right. \\
& \times \exp \left[-\frac{\left\{\left(x-x^{\prime}\right)+V\left(t-t^{\prime}\right)\right\}^{2}}{4 \varkappa_{1}\left(t-t^{\prime}\right)}\right] d x^{\prime} d t^{\prime} \\
& +2 \sum_{n=1}^{\infty} \alpha^{n} \int_{0}^{\infty} \int_{-b}^{0} \frac{\left(1-\frac{x^{\prime 2}}{b^{2}}\right)}{\left(t-t^{\prime}\right)} \\
& \times \exp \left[-\frac{\left\{\left(x-x^{\prime}\right)+V\left(t-t^{\prime}\right)\right\}^{2}+\left(2 n l_{c}\right)^{2}}{4 \kappa_{1}\left(t-t^{\prime}\right)}\right] \\
& \left.\times d x^{\prime} d t^{\prime}\right]
\end{aligned}
$$

ここで, $u=V\left(x-x^{\prime}\right) /\left(2 \varkappa_{1}\right)$ と置き, 無次元量を使っ

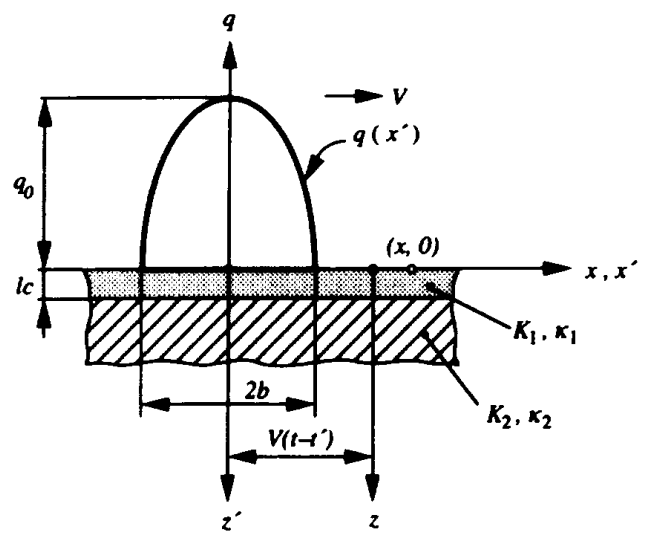

Fig. 10 Moving heat source and coordinates

て表すと式（5)は，

$$
\begin{aligned}
\theta & =\frac{2 q_{0} \varkappa_{1}}{\pi K_{1} V}\left[\int _ { x - L } ^ { x + L } \left(1-\xi^{2}+\frac{2 u \xi}{L}\right.\right. \\
& \left.-\frac{u^{2}}{L^{2}}\right) K_{0}(u) e^{-u} d u \\
& +2 \sum_{n=1}^{\infty} \alpha^{n} \int_{x-L}^{x+L}\left(1-\xi^{2}+\frac{2 u \xi}{L}-\frac{u^{2}}{L^{2}}\right) \\
& \left.\times K_{0}\left\{\sqrt{u^{2}+(2 n L \delta)^{2}}\right\} e^{-u} d u\right]=\frac{2 q_{0} \varkappa_{1} T}{\pi K_{1} V}
\end{aligned}
$$

となる.

\section{文献}

（1）福永圭悟・坂本正史・稲田斉，機論，52-481, C (1986)，2472 -2478 .

（2）岩野利彦・殿塚文彦，金属材料，15-4 (1975)，13-32.

（3）灌野宏正-中迫证-一河野正来，機論，61-592，C(1995), 4763-4768.

（4）大野僼・磯田和男監修，新版数值計算ハンドフック， (1990)，147，才一公社

（5）松永正久監修・津谷裕子編集，固体潤滑ハンドフック (1982)，90，幸書房.

（6）寺内吉男 - 篧野宏正, 機論, 47-423, C (1981), 1502-1508.

（7）日本金属学会・日本鉄㙝会編，鉄鎆材料便筧，(1967)， 608, 丸善.

（8）ギート著, 横塌進・久我修共訳, 基礎伝熱工学、(1964)，322， 丸善. 